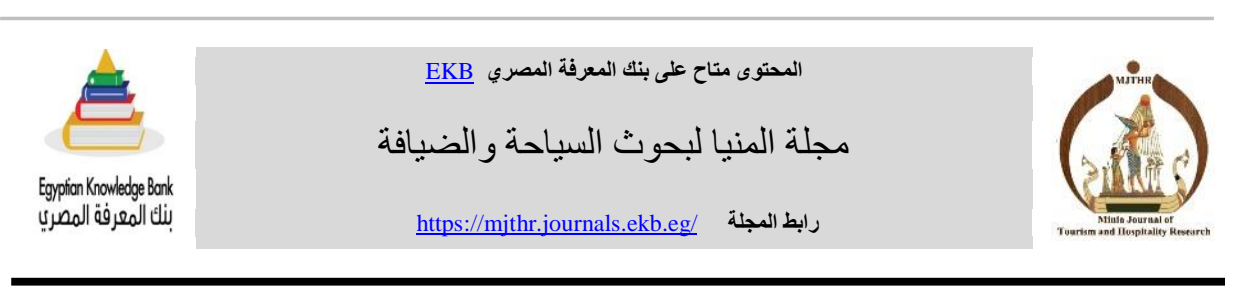

\title{
واقع التنمية المستدامة في قرية البهنسا بمحافظة المنيا
}

\author{
أ ـ د / سماح عبدالرحمن محمود '

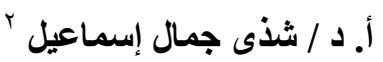

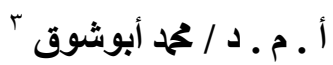 \\ كريستينا عادل فتحي كامل ؛
}

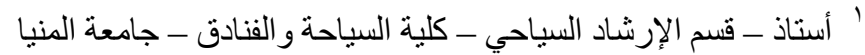

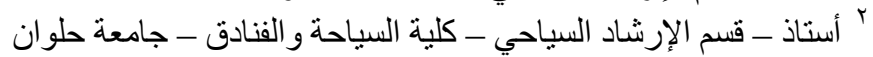

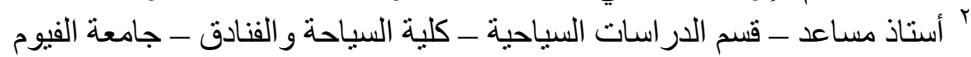

؛ باحثة دكتور اة - كلية السياحة و الفنادق - جامعة المنيا

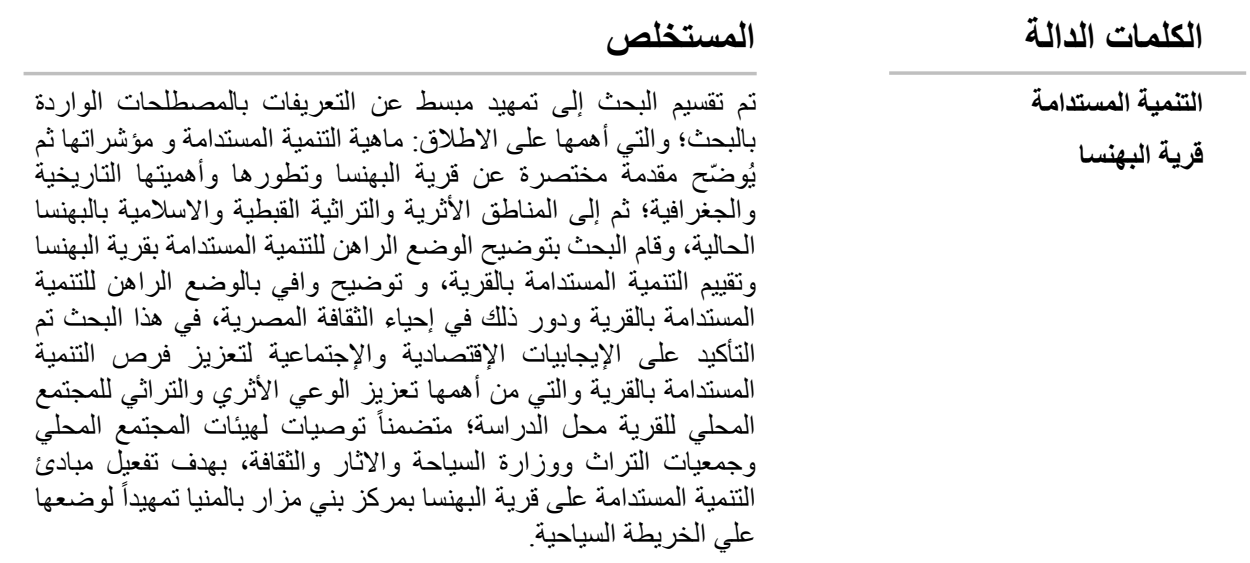

Printed ISSN 2357-0652 Online ISSN 2735-4741 


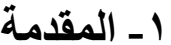

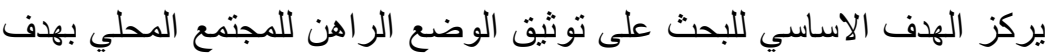

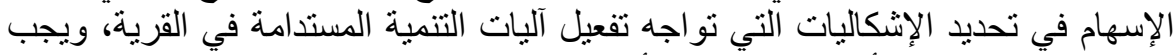

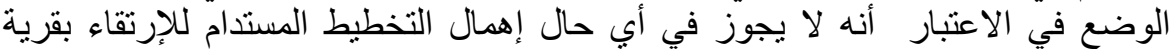

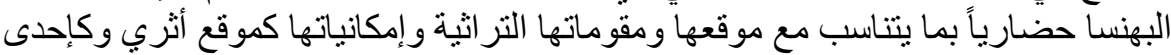

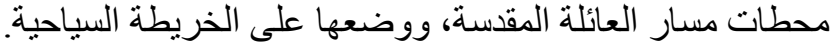

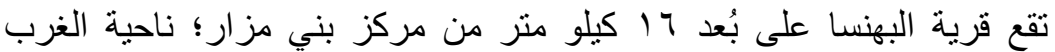

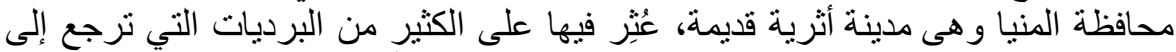

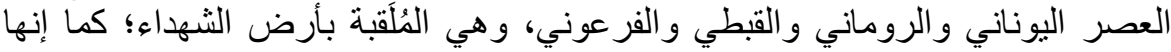

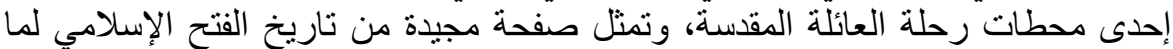

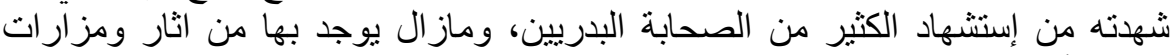

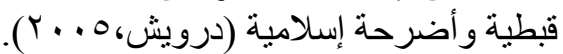

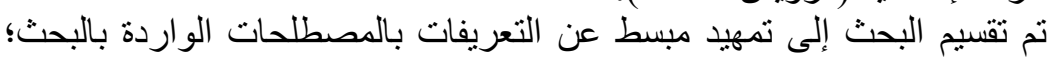

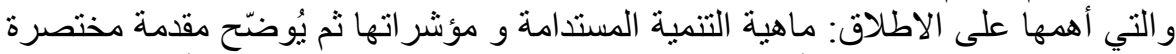

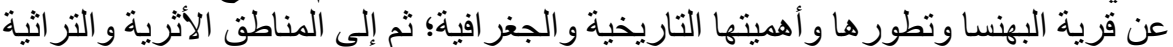

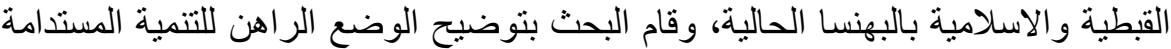

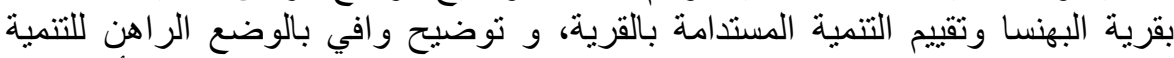

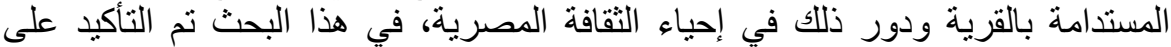

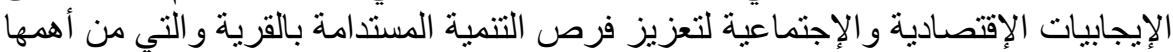

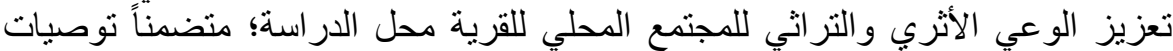

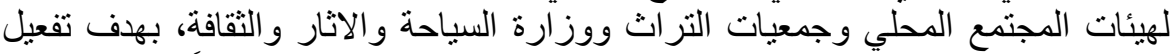

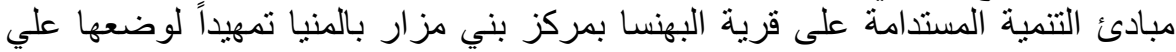
الخريطة السياحية.

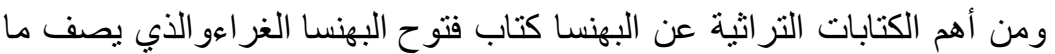

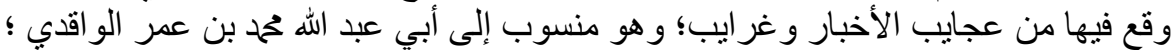

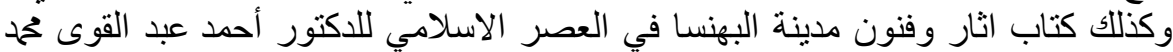

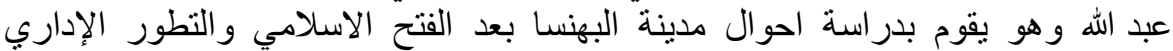

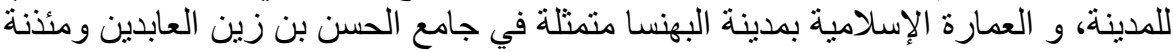

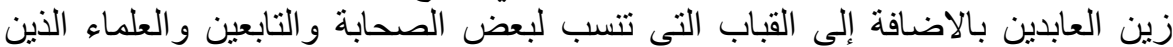

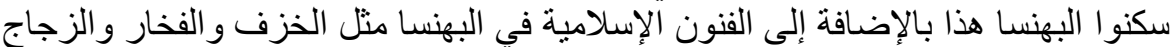

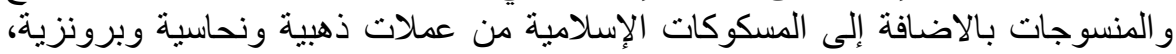

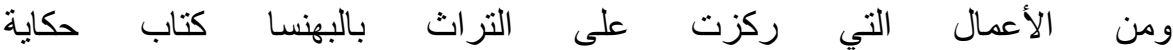

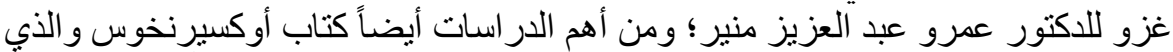

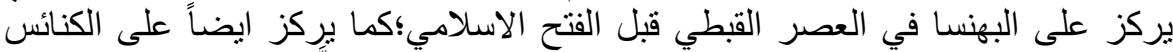

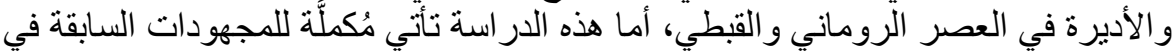
توصيف الوضع الر اهن للبهنسا ومعوقات التنمية المستدامة بالقرية.

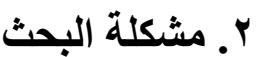

تبني البحث دراسة الوضع الراهن لهُ لقرية البهنسا للتوصل لإشكاليات تطبيق آليات التنمية

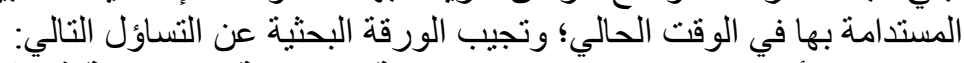

ـ ما هي أهم العقبات التي تواجه التنمية السياحية المستدامة في قرية البهنية البهاب 


\section{r. منهجية البحث}

تم الإعتماد على منهج در اسة الحالة والذي بتطلب تحليلاً كاملاً لكافة البيانات التي

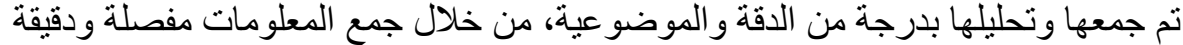

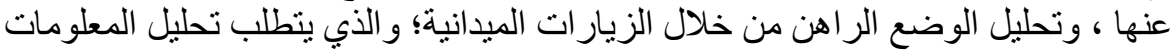

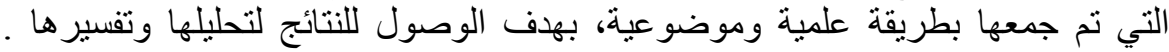

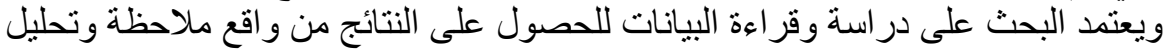

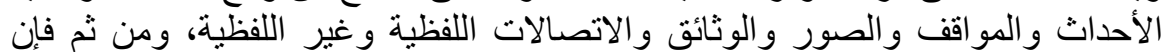

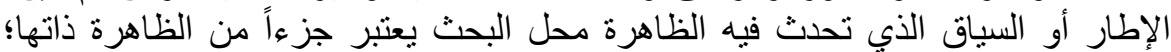

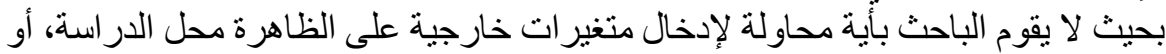

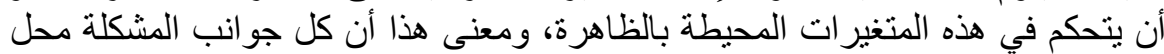

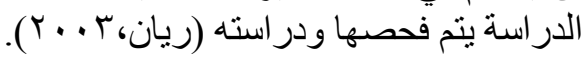

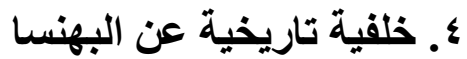

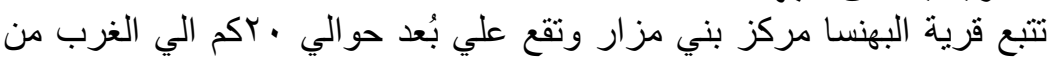

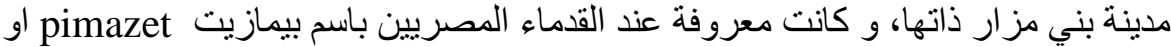

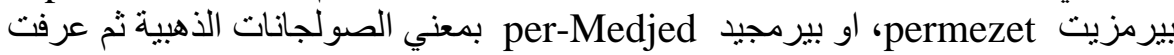

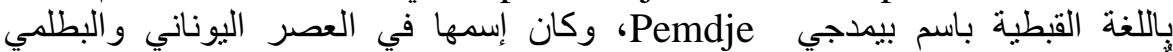

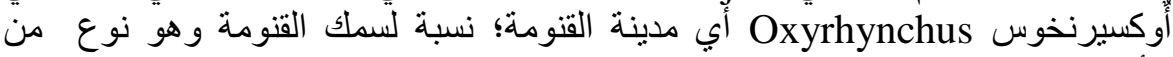

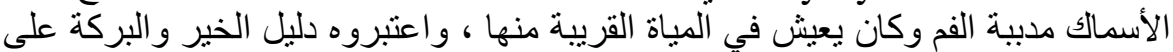

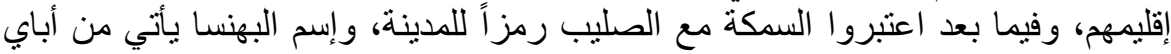

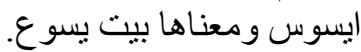

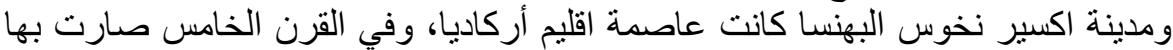

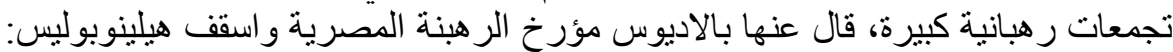

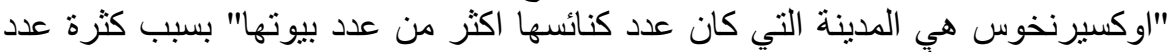

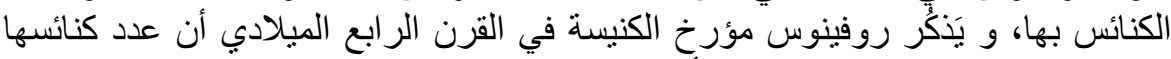

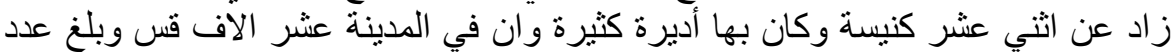

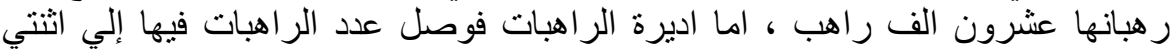

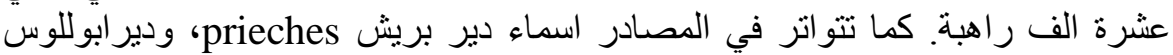

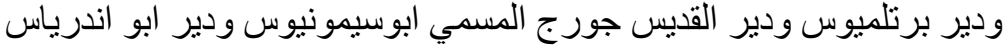

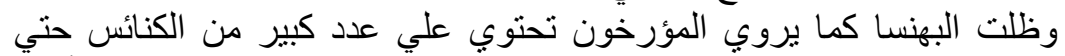

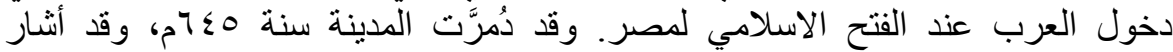

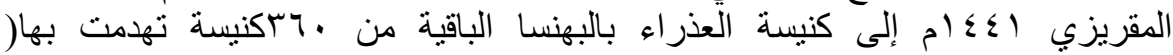

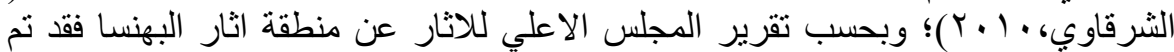

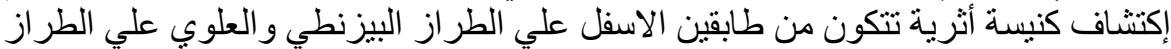

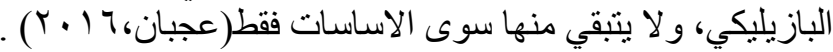

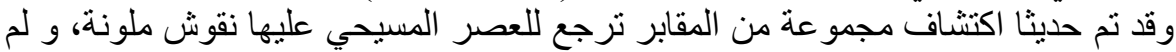

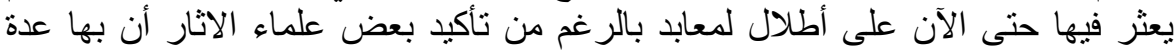

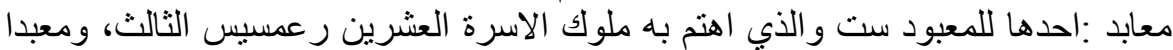

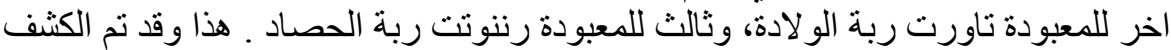

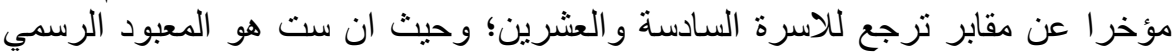
للمدينة، وقد تم الكثف عن مقبرتين كبيرتين ترجعان للعصر المتأخر وتؤرخان بالاسرة 


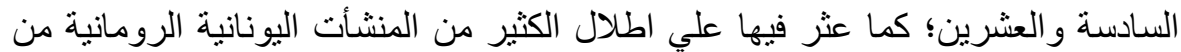

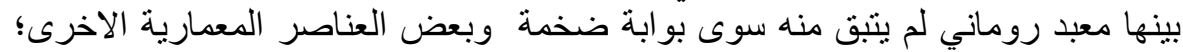

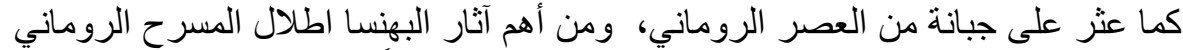

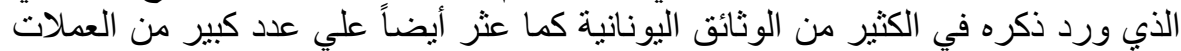

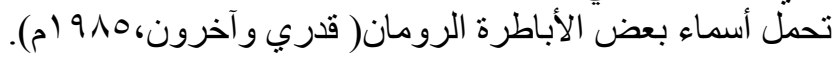

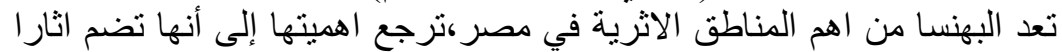

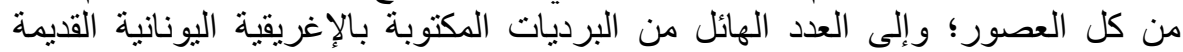

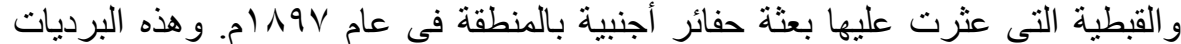

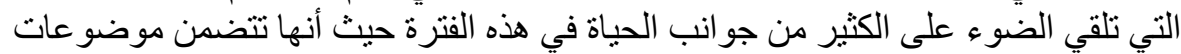

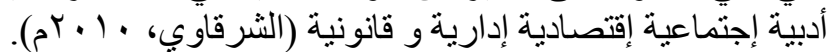

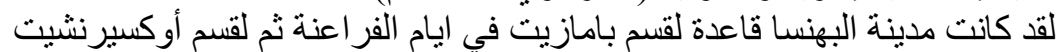

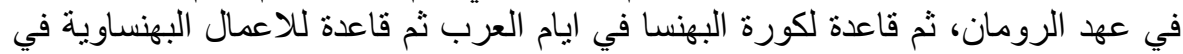

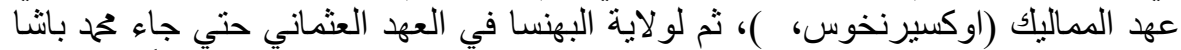

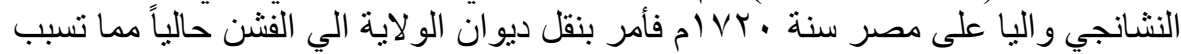

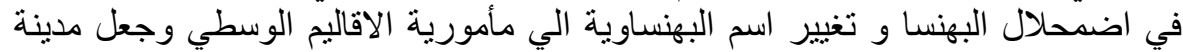

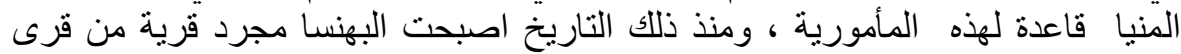

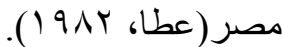

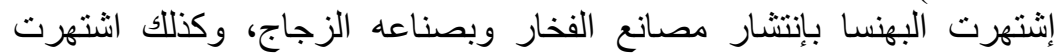

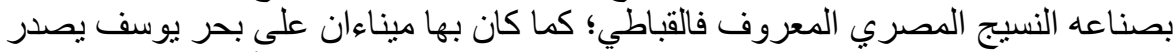

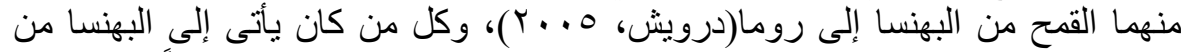

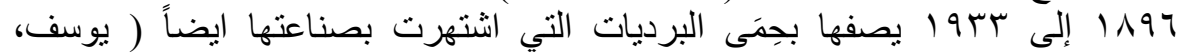

\section{هـ تراث قرية البهنسا}

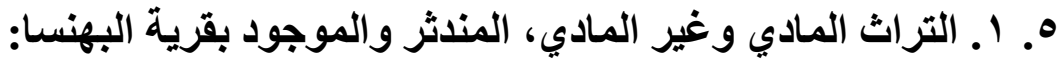

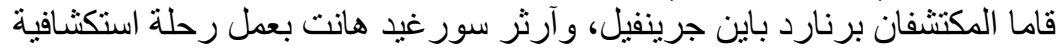

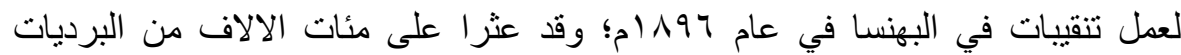

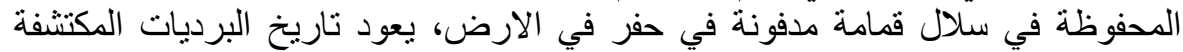

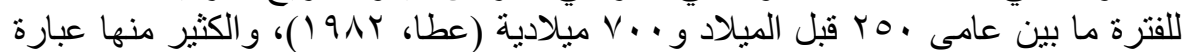

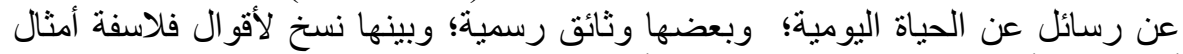

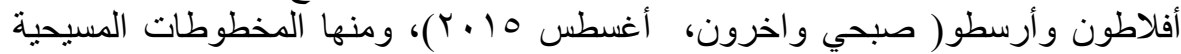

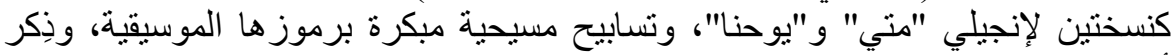

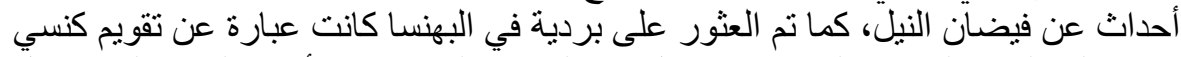

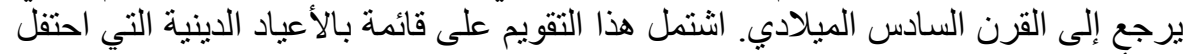

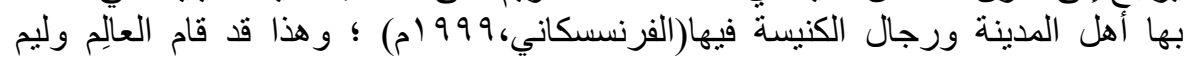

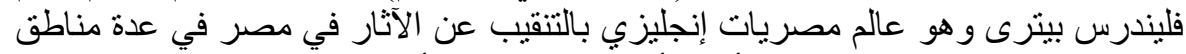

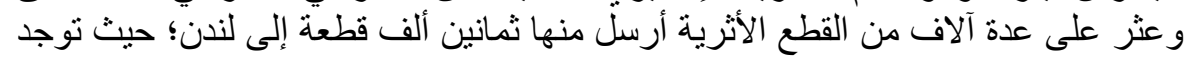

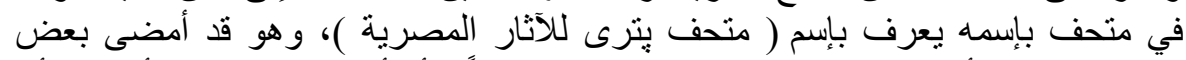

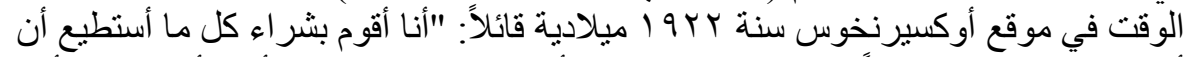

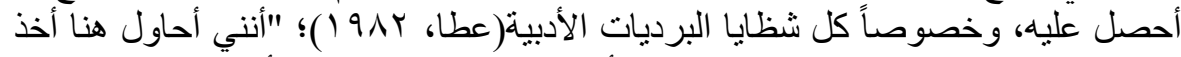

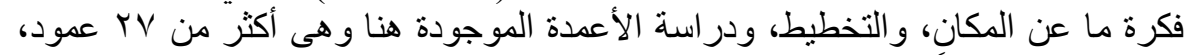

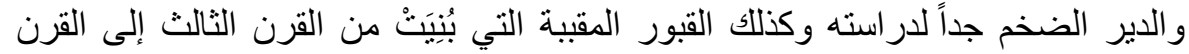


السادس الميلادي" (اوكسيرنخوس)، البرديات التي نُقِلَتْْ إلى لندن بو اسطة السيدان برنارد

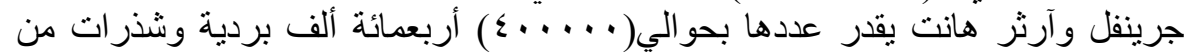
البرديات غير الآلاف التي نقلها بيترى إلى لنى لندن"(نزيها

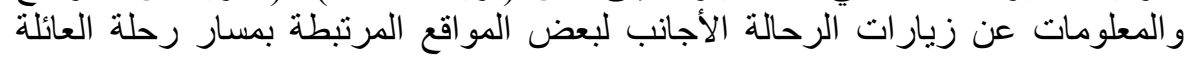

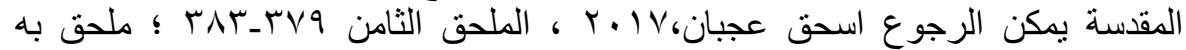
تسجيل لأغلب زيارات الرحالة الأجانب لبعض المضان المع المن المرتبطة بمسار رحلة العائلة

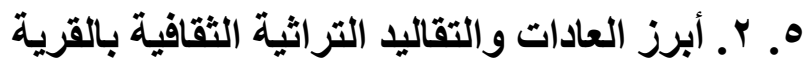

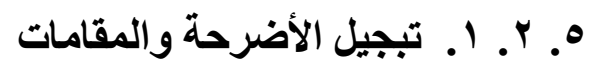

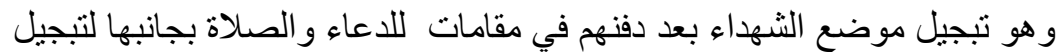

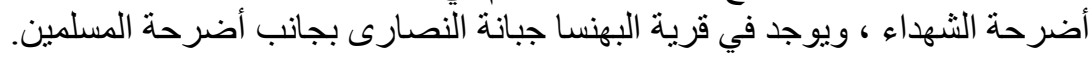

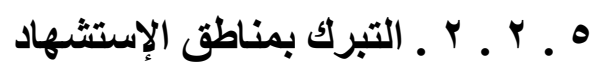

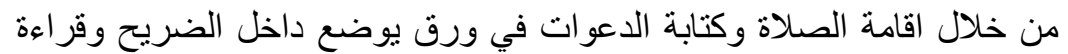
الفاتحة عند الضريح. الاستشفاء بالتصرغ في أرض الصحابة في قرية البهنسا؛ عند حجر الاحرجة

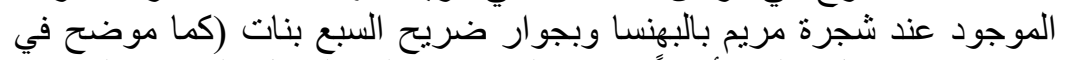

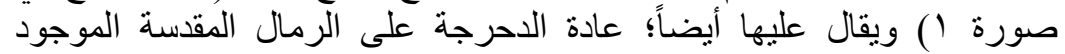
بالبهنسا.

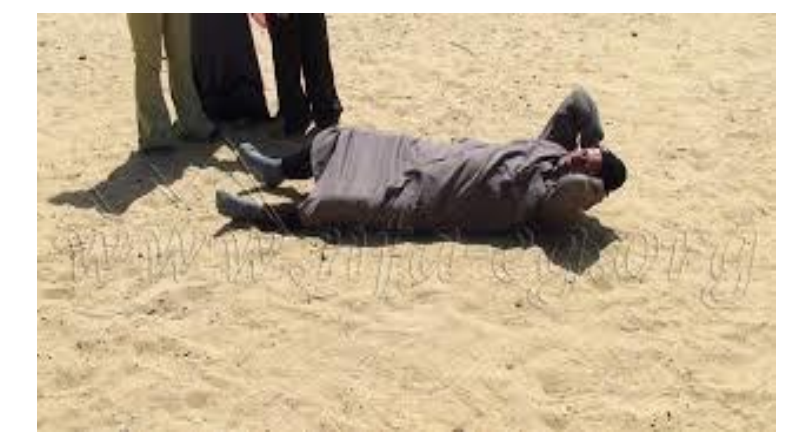

صورة ( 1 ) تبين تراث الاحرجة أمام ضريح السبع بنات بقرية البهنسا

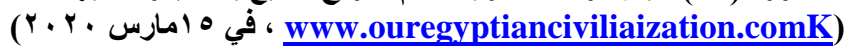

\section{هـ بـ أهم الاثار المسيحية الباقية في البهنسا}

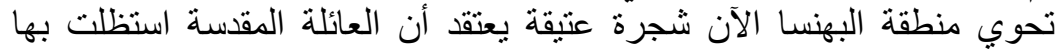

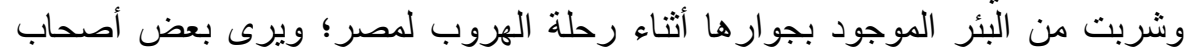

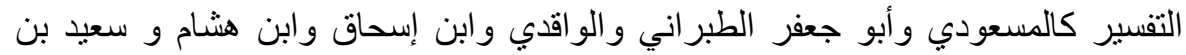

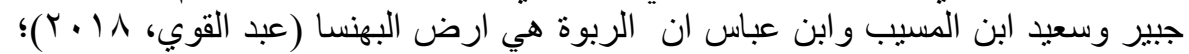

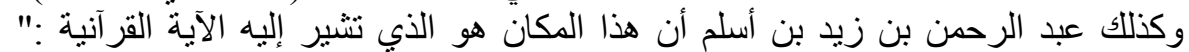

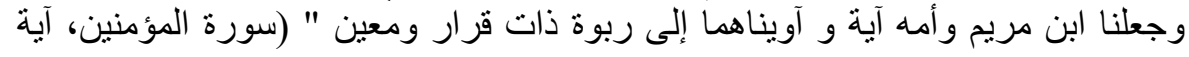




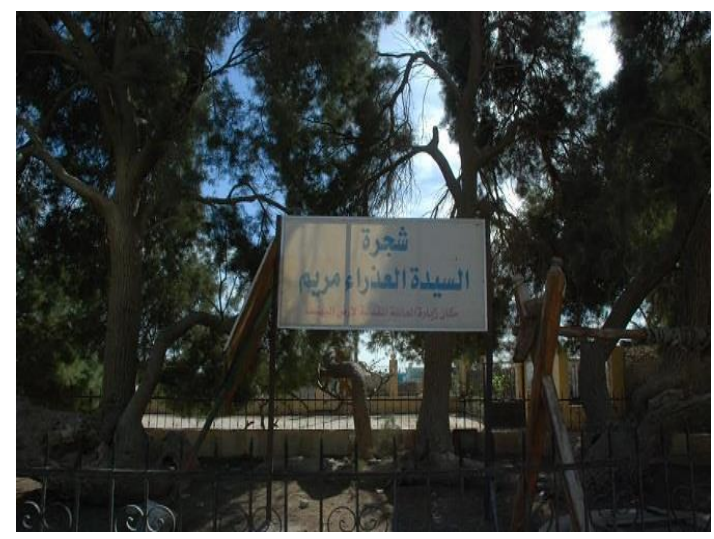

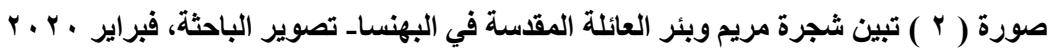

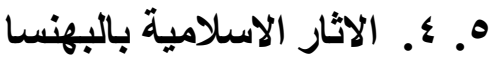

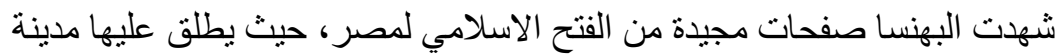

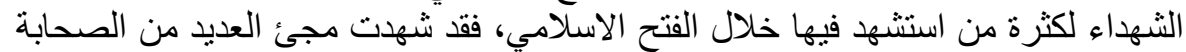

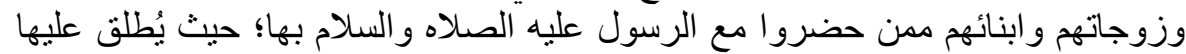

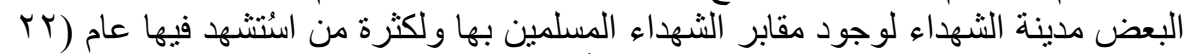

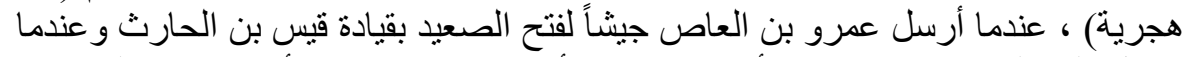

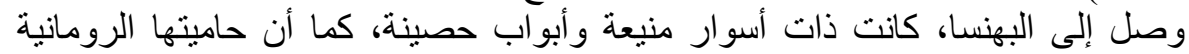

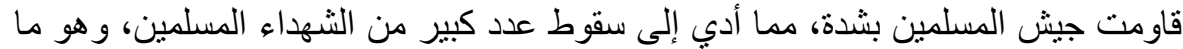

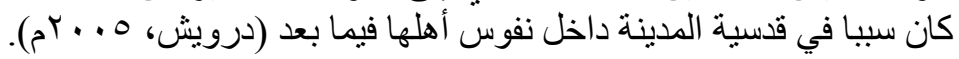

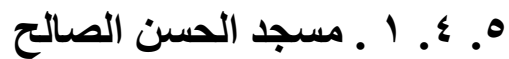

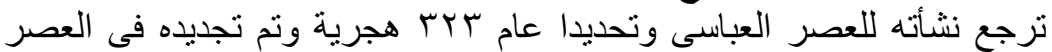

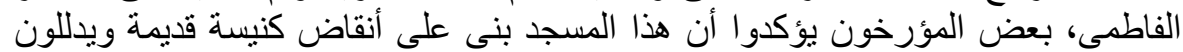

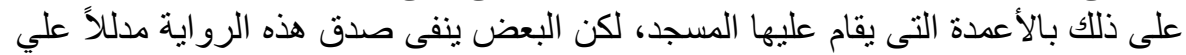

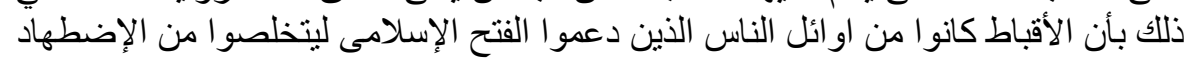

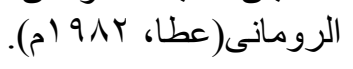
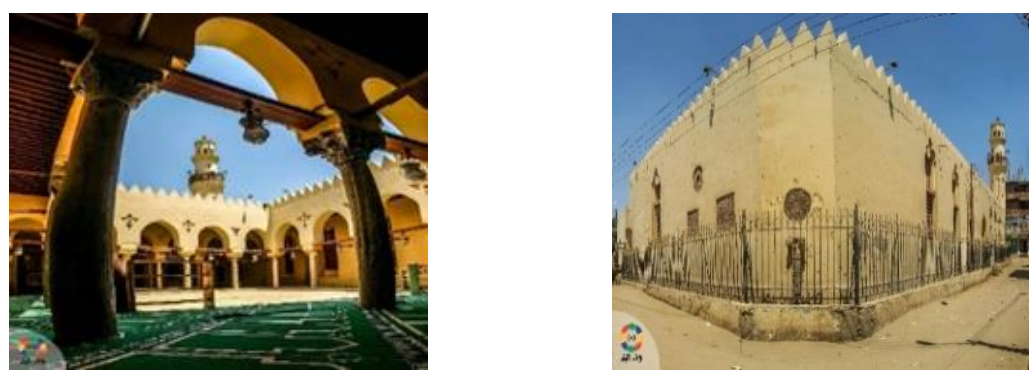

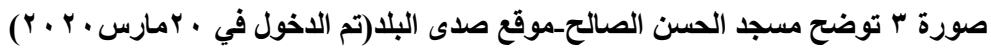




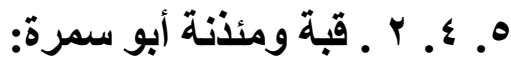

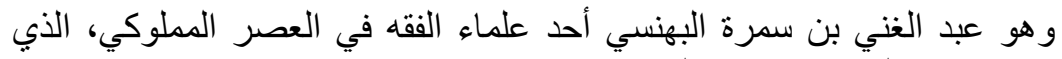

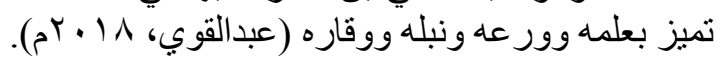
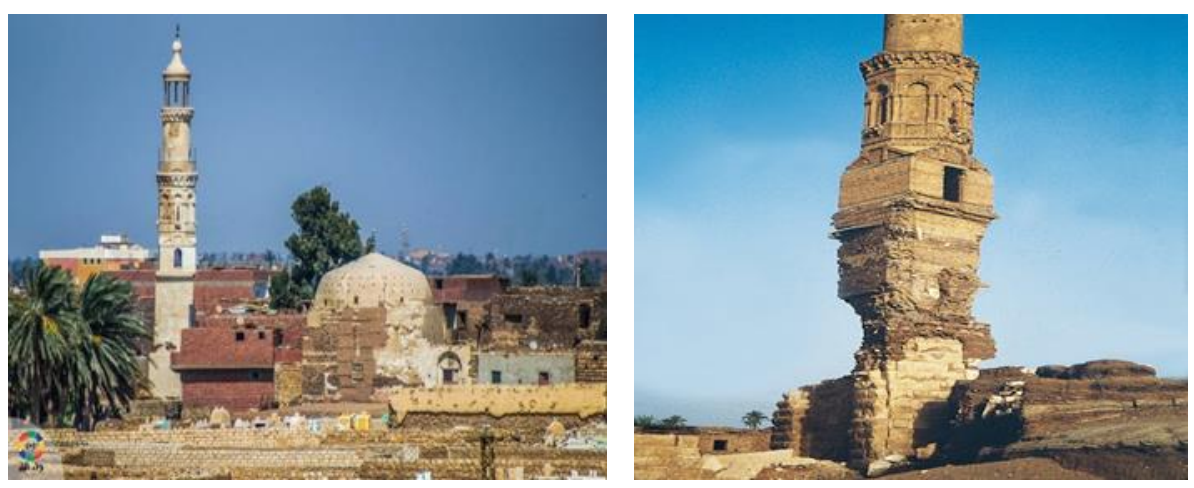

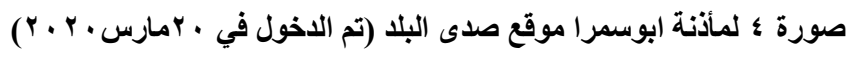

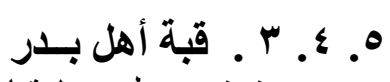

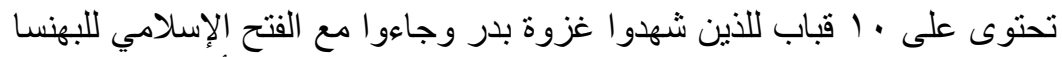

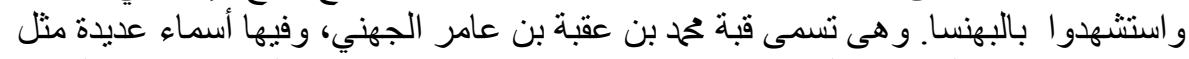

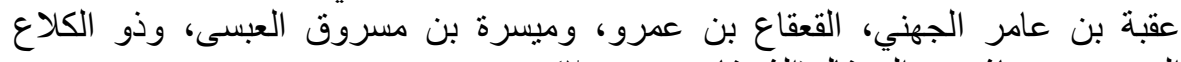

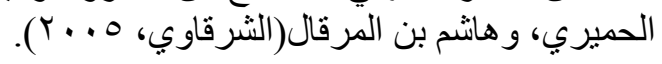
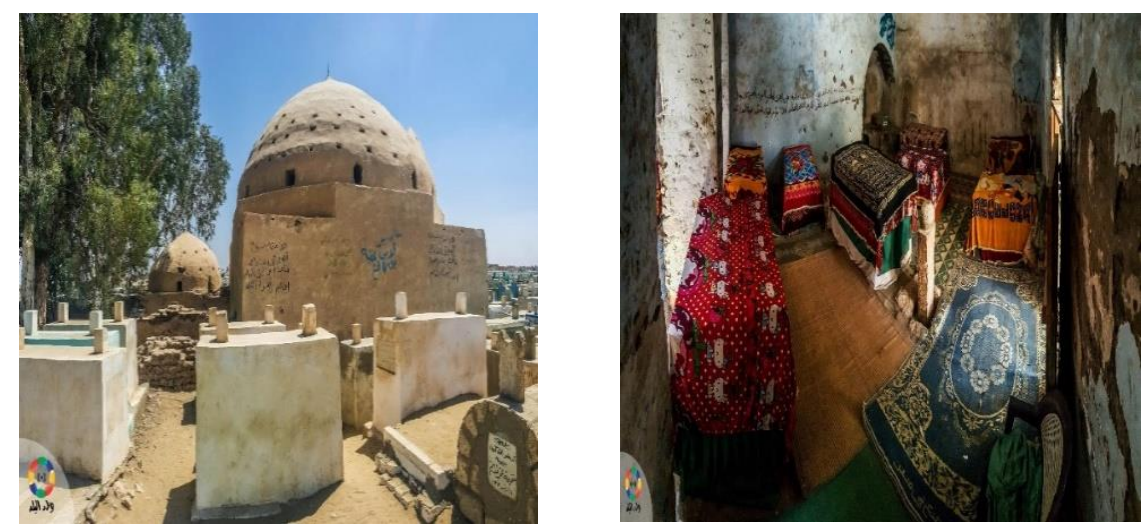

$$
\begin{aligned}
& \text { صورة ه قبة أهل بلر من الداخل والخارج - موقع صدى البلد (تم الاخول في }
\end{aligned}
$$

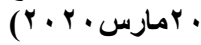

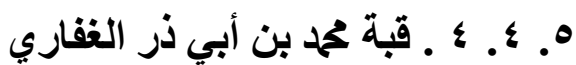

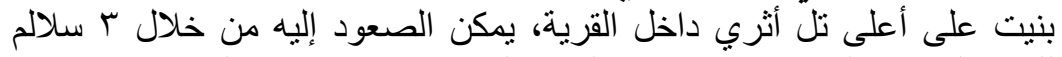

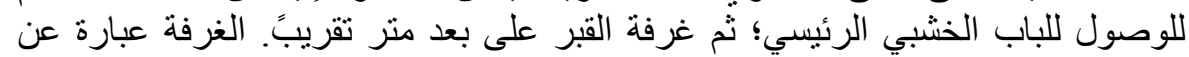

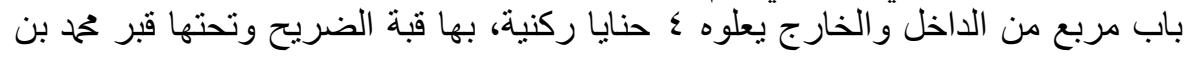




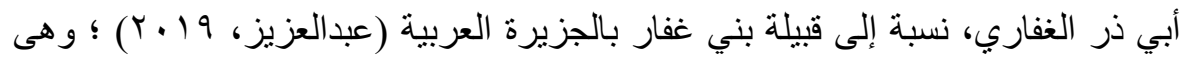

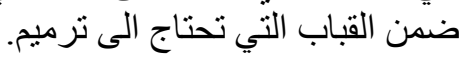

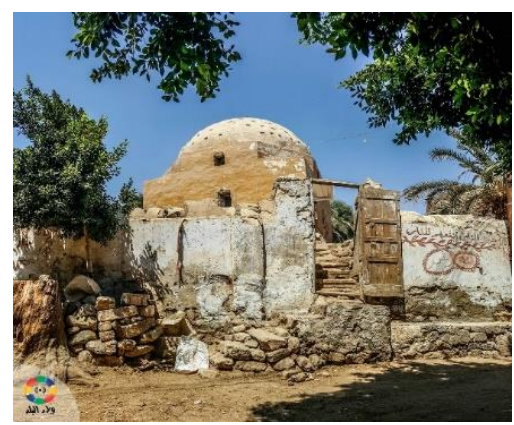

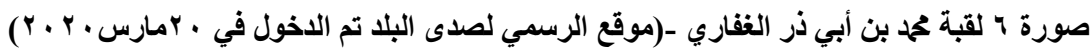

๑. ع. • ـ قبة أبان بن عثمان بن عفان

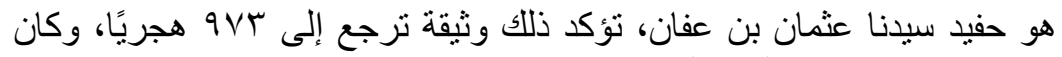

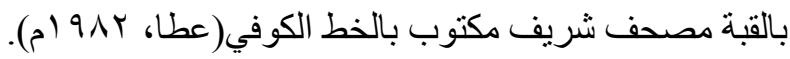

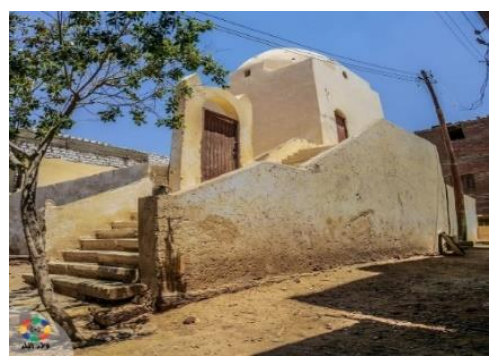

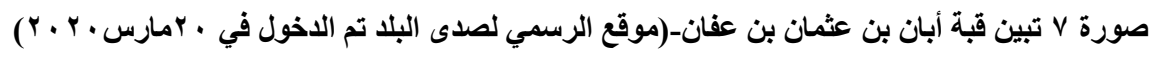

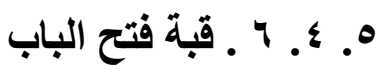

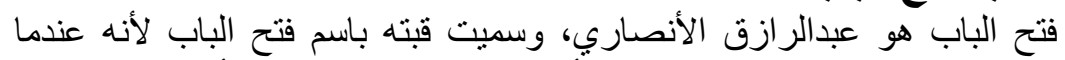

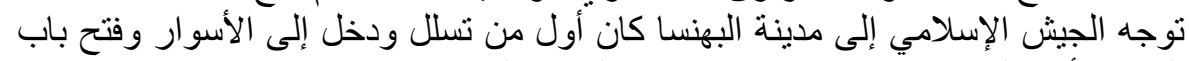

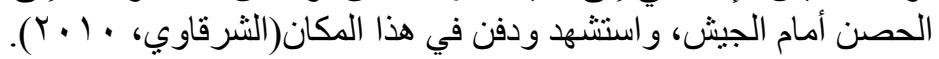

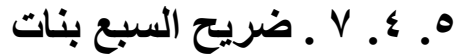

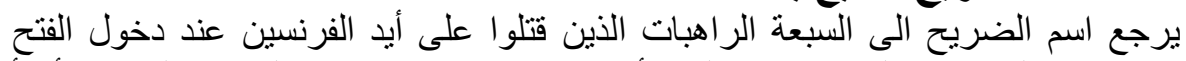

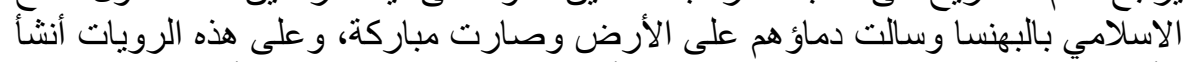

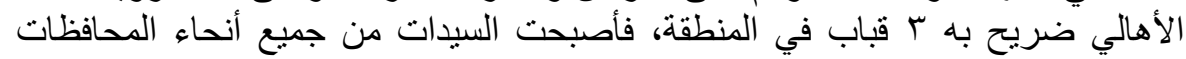

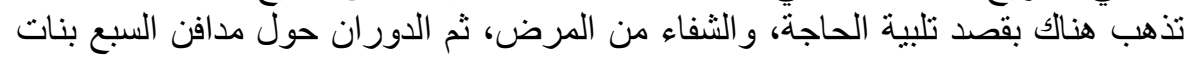

عدة مر ات()). 


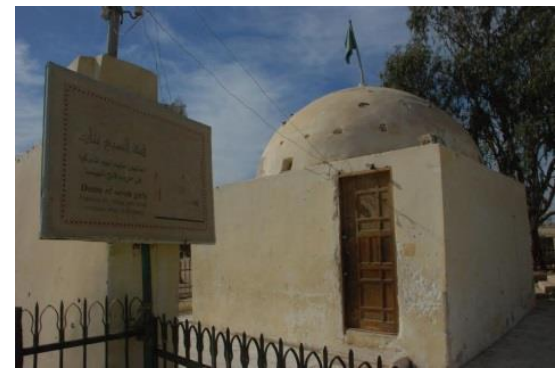

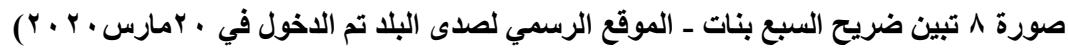

فضلاً عن العديد من المساجد والأضرحة الخاضعة لهيئة الآثار الاسلامية

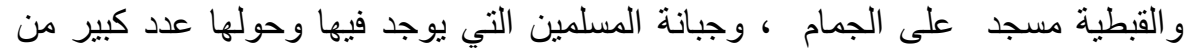

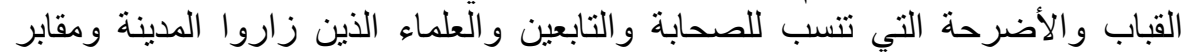

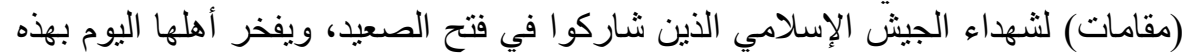

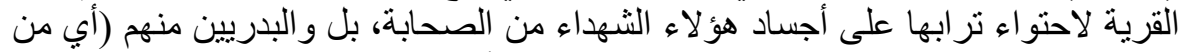

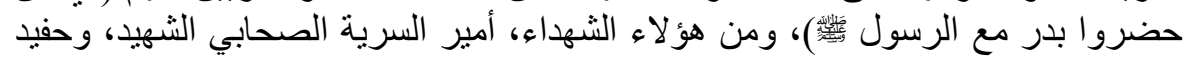

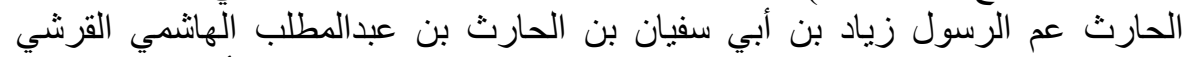

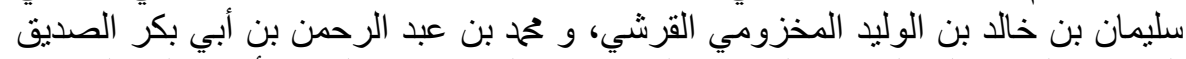

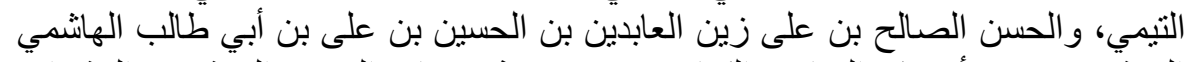

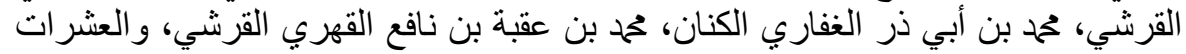
ممن شاركوا في الفتوحات الإسلأمية.

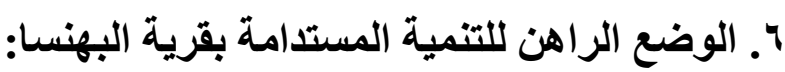

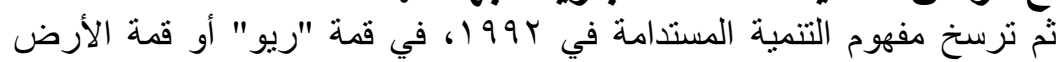

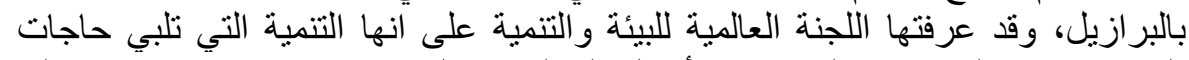

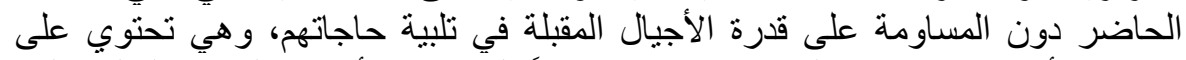

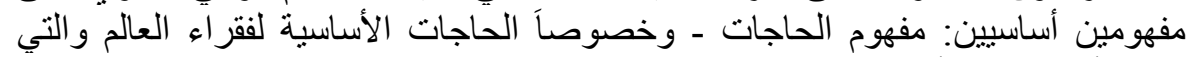

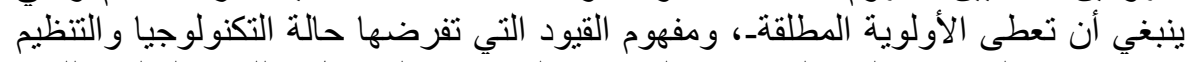

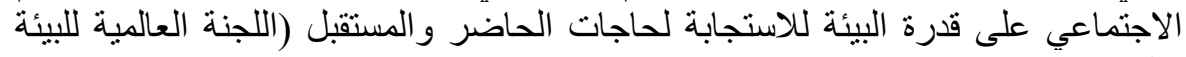

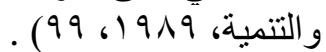

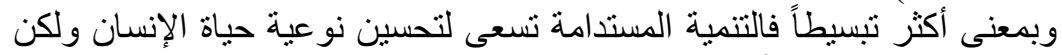

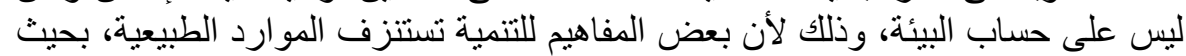

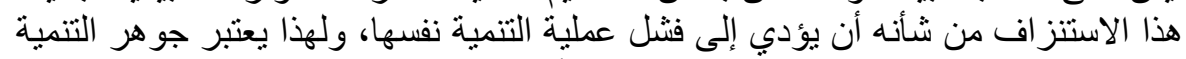

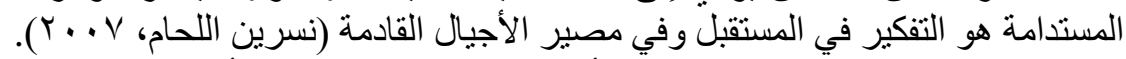

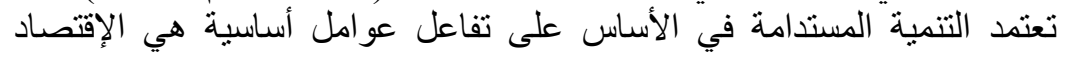

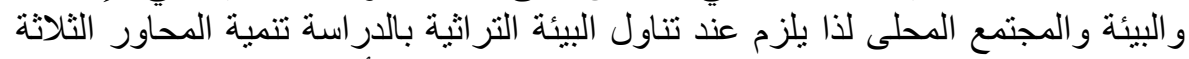

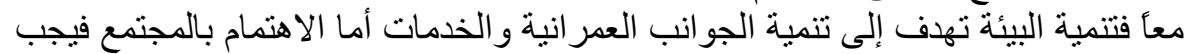

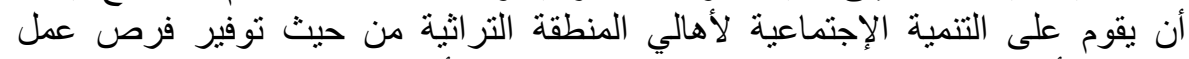

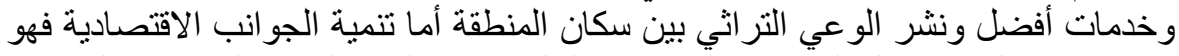

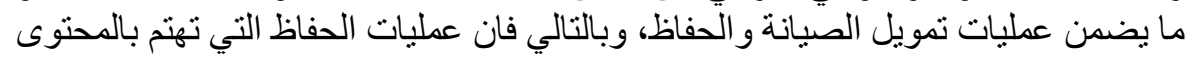

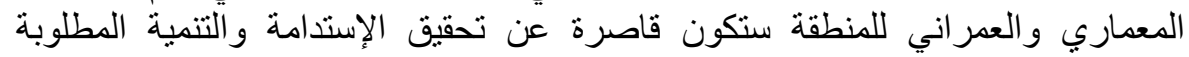

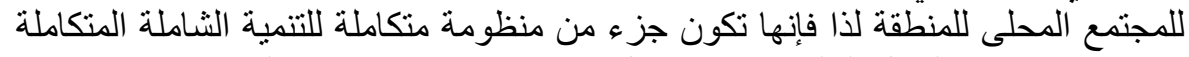

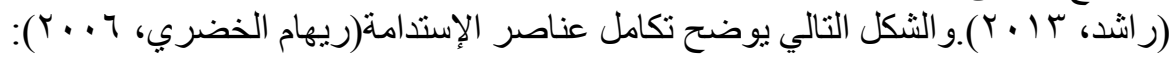




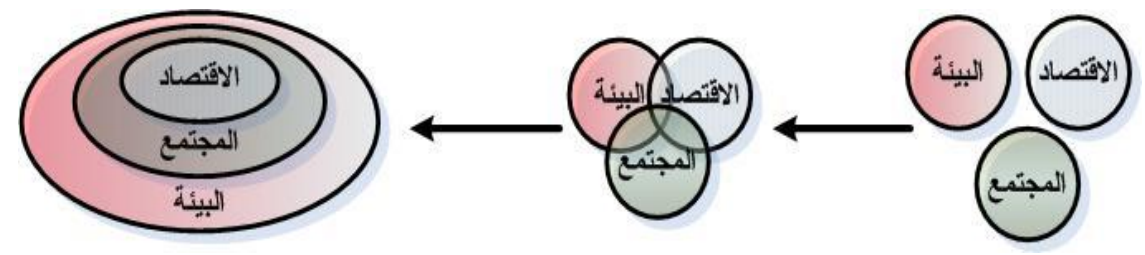

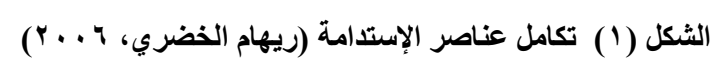

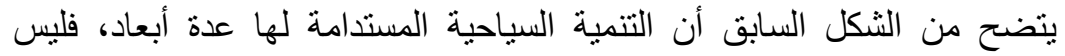

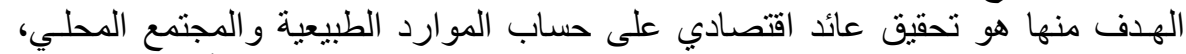

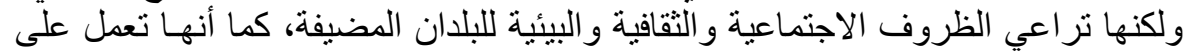

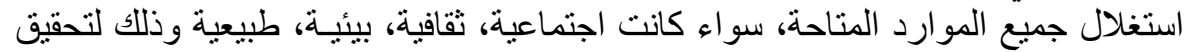

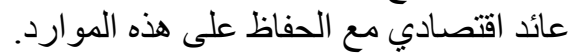

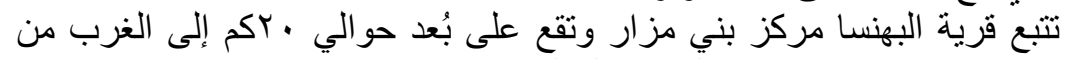

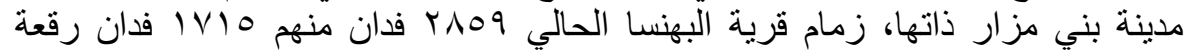

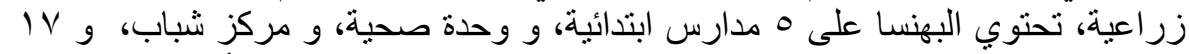

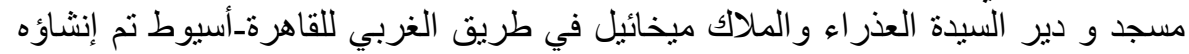

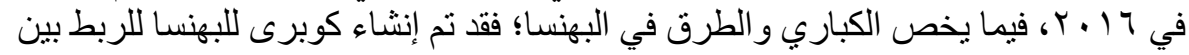

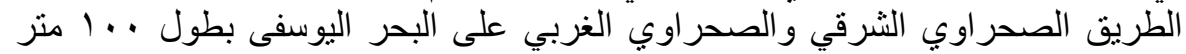

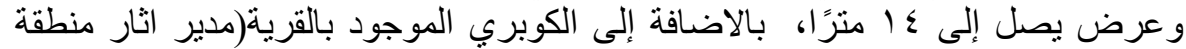

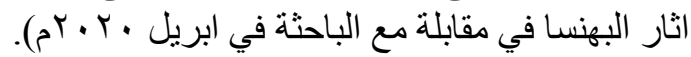
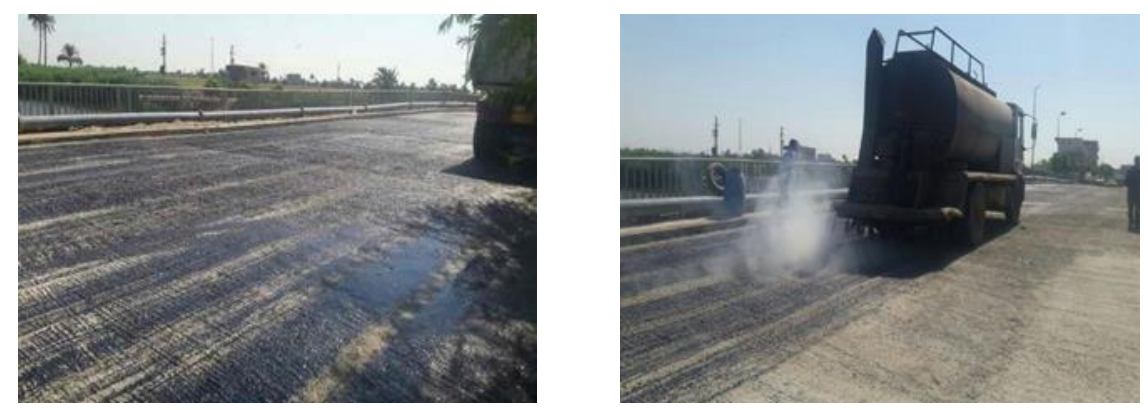

صورة 9 تبين أعمال رصف كوبري البهنسا- تصوير الباحثة يناير ·r ·r م

أعدت إدارة السياحة بمحافظة المنيا بالتعاون مع وزارة الاثار ووزارة السياحة

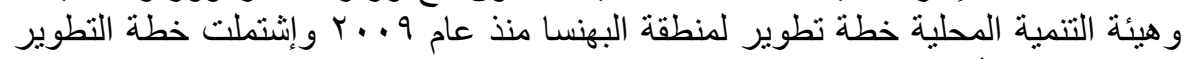

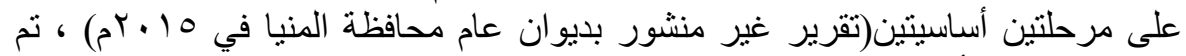

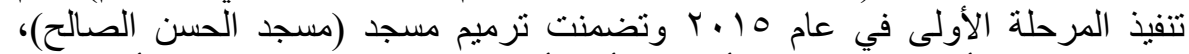

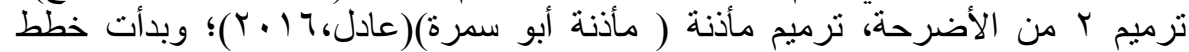

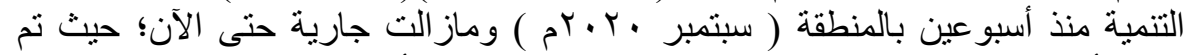

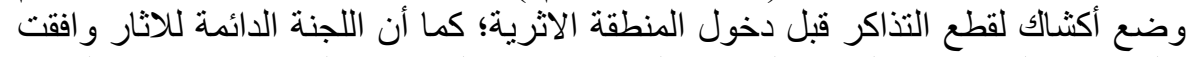

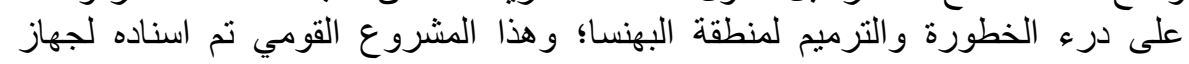


مشروعات الخدمة الوطني؛ حيث قامت لجنة بزيارة المنطقة وعاينت كل الأضرحة بها

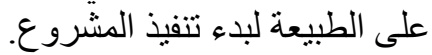

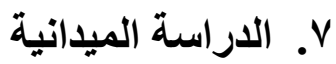

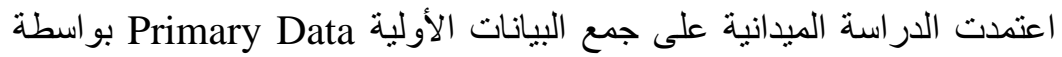

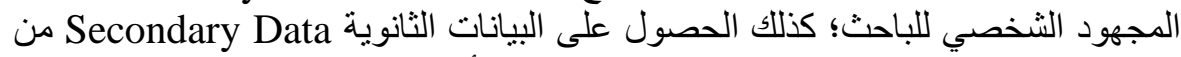

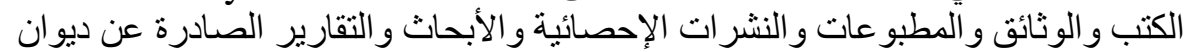

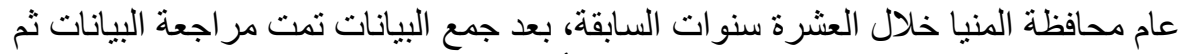

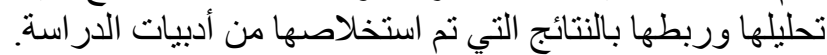

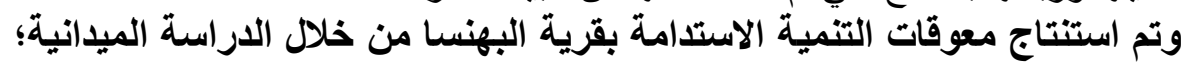

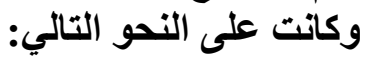

V . 1 ـ معوقات مرثبطة بالمجتمع المحلي

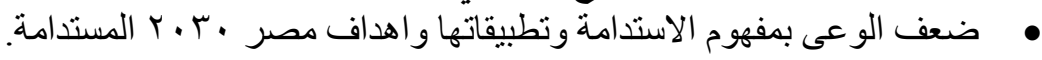
ضعف مستوى المعيشة .

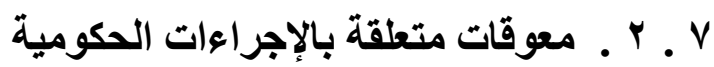

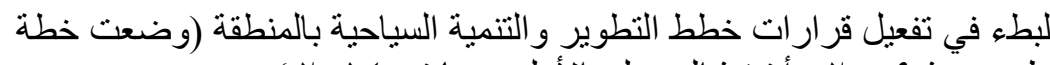

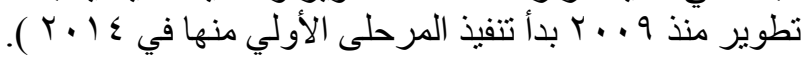
عقد إجتماعات ودر اسات دون تفعيل توصياتها.

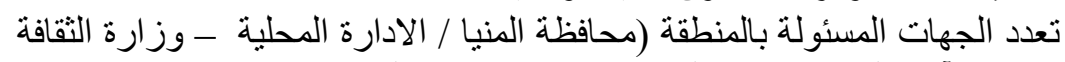
/ منطقة آثار المنيا ـ وزارة السياحة / مكتب تنشيط السياحة ).

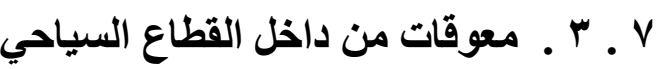

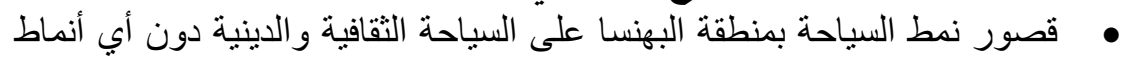

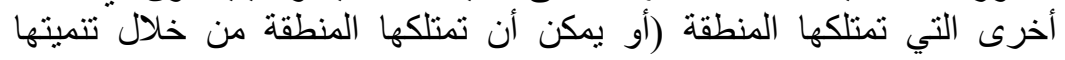
و الإهنمام بها).

ضبعف برامج التسويق السياحي الإلكتروني أوالورقي لمقومات الجذب السياحي بالمنطقة. عدم دمج الدر اسات والأبحاث العلمية بالو اقع العملي ولو حتى على سبيل الإسنفادة عدم الإهتمام الحقيقي بكل وظائف التخطيط السياحي الذي يقوم على التقدير

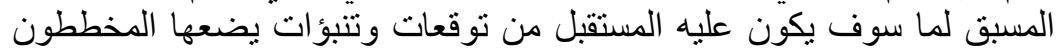

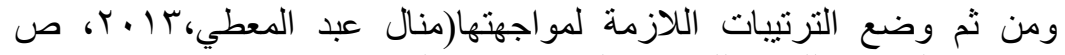

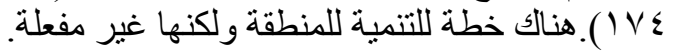

\section{1 ـ التوصيات}

المر اقبة المكثفة: قد لا تكون الدر اسات و التشريعات كافية وحدها لحماية المباني

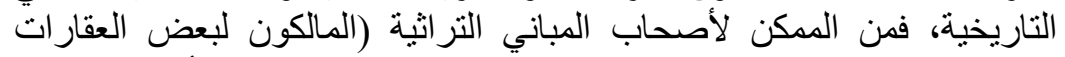

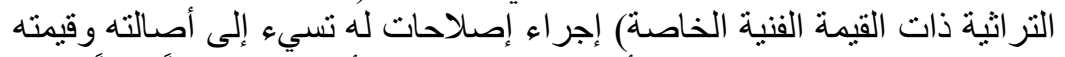

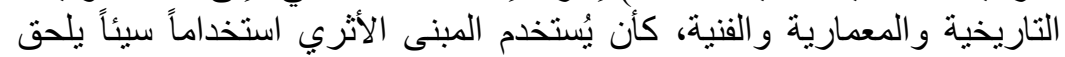
الضرر به، و الأمر هنا يحتاج إلى نظم وسياسات لفئه لحمايته. 
التوعية: وتتلخص بتعريف المواطن على أهية الآثار الثقافية والاقتصادية له له

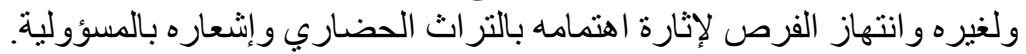

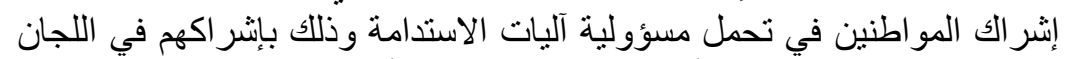

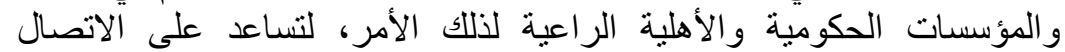

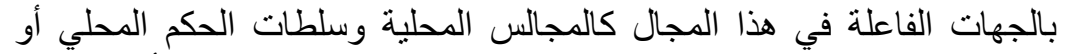

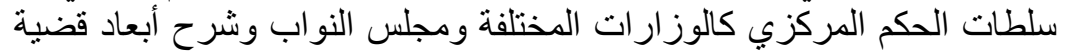

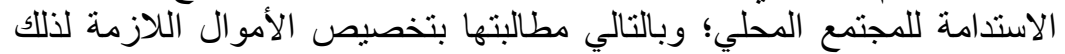
و إصدار التشريعات المؤيدة للاستدامة.

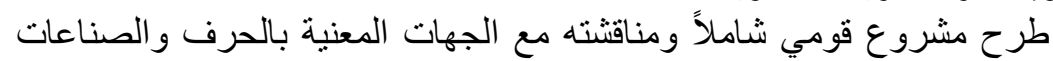

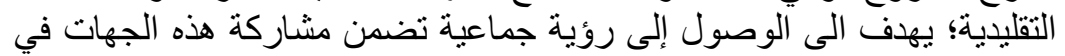

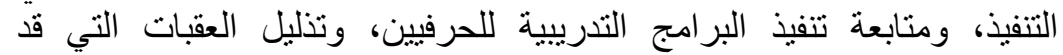

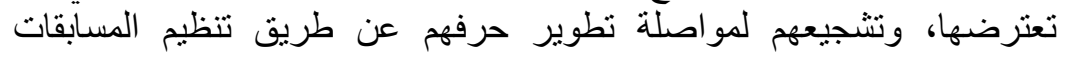

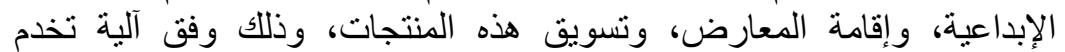

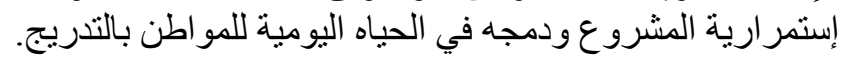

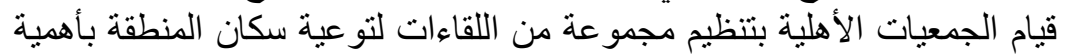

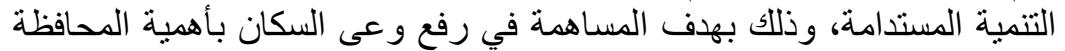

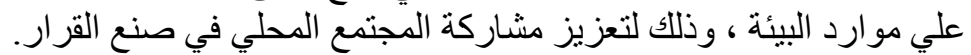

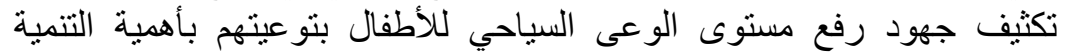

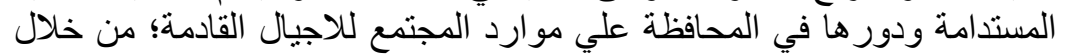

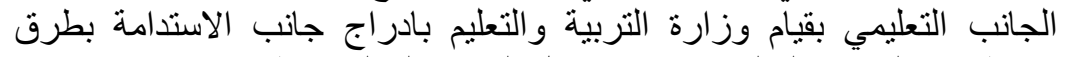

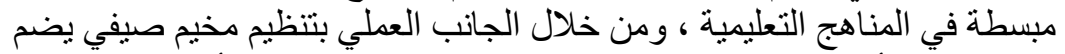

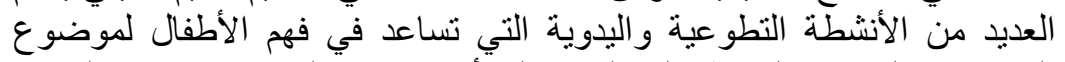

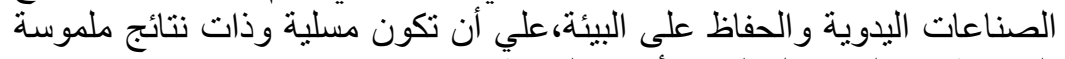
تلفت نظر هم الي جمال الييئة و أهمية الحفاظ.

قام البحث بدراسة واقع قرية البهنسا وجمع بيانات عن الخدمات و عدد الددرس إلها

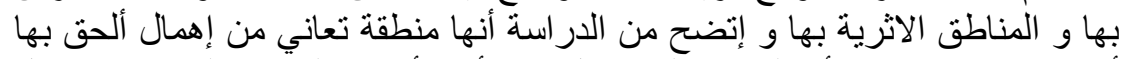

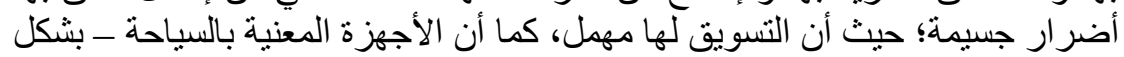

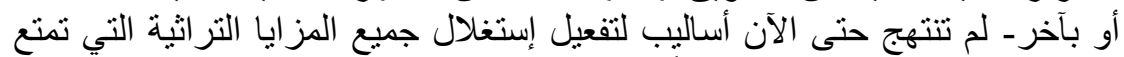

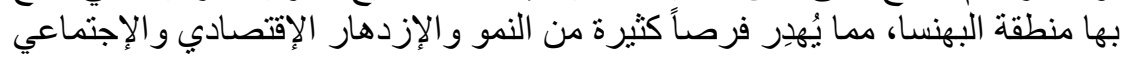

ألقىى البحث الضوء على منطقة لها قيمة تر اثية و أثرية ثمينة كقرية البهنسا وكما و الثقافي.

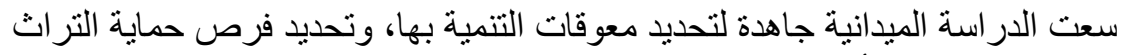

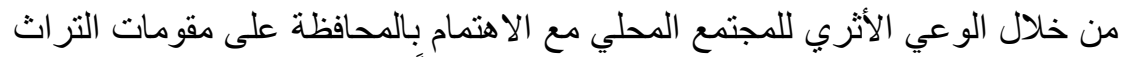
الحضاري و الثقافي و الطبيعي بها؛ لتكون مؤهله سياحياً لإستقطاب السياحة الدولية. 


\section{9. أبحاث مستقبلية مقترحه

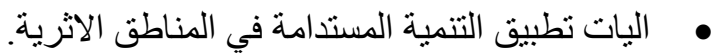 \\ استر اتيجيات تطبيق الاستدامة بقرية البهنسا.}

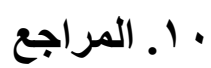

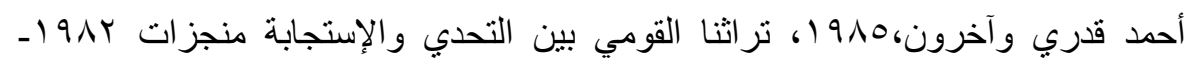
1910 ، سلسلة الثقافة الأثرية والتاريخية مشروع المائة كتاب،مطبعة هيئة الآثار

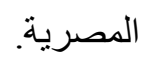

أحمد إبر اهيم عطية، ه . . Y، قانون حماية الآتار المو اثيق الدولية والقانون الدصري، طبعة أولى، الدار العالمية للنشر والتوزيع.

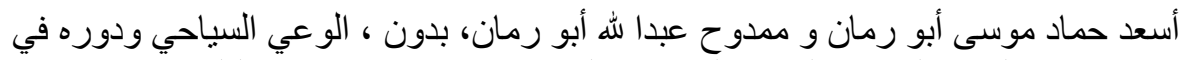
تعزيز القدرة التنافسية لقطاع السياحة و السفر في الاردن: دراسة لتحليلية ميدانية. أنطون يوسف، ب ج 9 (، لمحة تاريخية عن الآثار المصرية، المنيا، مطبعة محمود محح. وزارة الثقافة، ديوان عام محافظة المنيا، المنيا عروس الصعيد، إصدار محافظة المنيا. اليونسكو 910 (، الإتفاقيات و التوصيات التي أقرتها اليونسكو بشأن حماية التراث الثقافي .

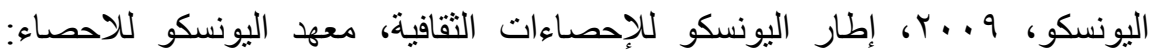
http://www.uis.unesco.org/culture/Documents/frameworkcultural-statistics-culture-2009.pdf باسم سمير الثرقاوي، ه. . ب، محافظة المنيا المواقع الأثرية و المزارات الدينية، المجلس

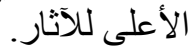

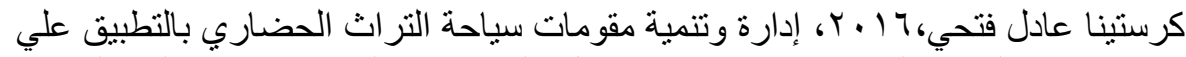
كنيسة السيدة العذراء الاثرية بدير حبل الطير، رسالة ماجستير، كلية السياحة

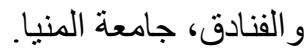

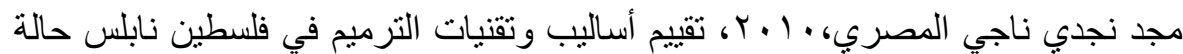

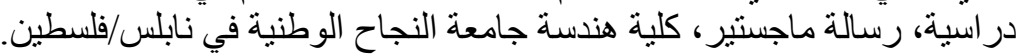

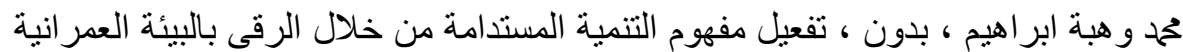

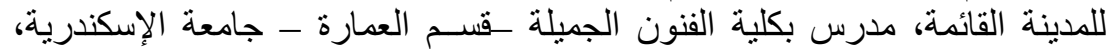
جامعة القاهرة ،كلية الهندسـة.

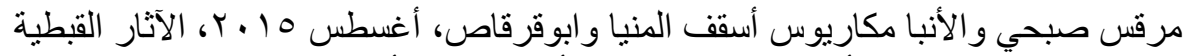

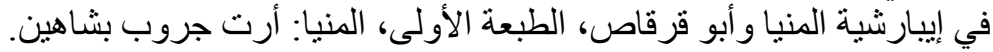

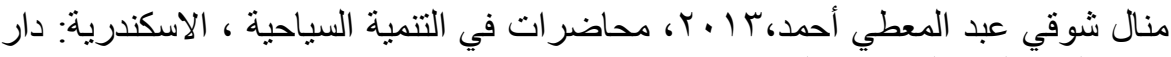
الوفاء لدنيا الطباعة و النشر ـالإسكندرية.

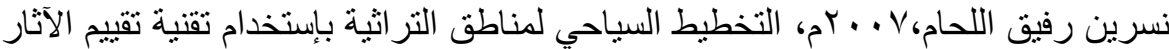
البيئية، القاهرة: دار النيل للنشر و الطبع وألتوزيع. 


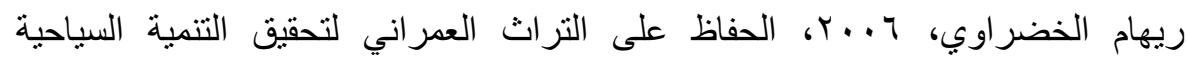

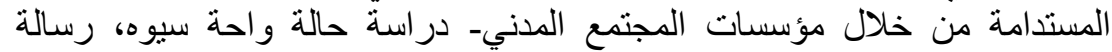

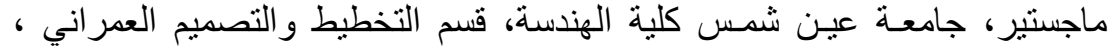

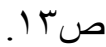

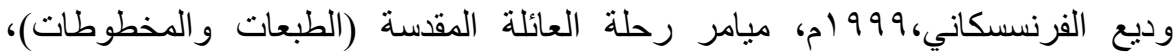

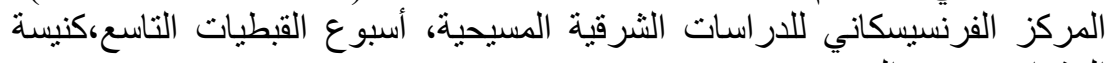
العذر اء بروض الفرن. 